April 2011

\title{
Research Note: American Initiatives for the Relief of Greek \\ Refugees, 1922-1923
}

Antonis Klapsis

Follow this and additional works at: https://digitalcommons.usf.edu/gsp

\section{Recommended Citation}

Klapsis, Antonis (2011) "Research Note: American Initiatives for the Relief of Greek Refugees, 1922-1923," Genocide Studies and Prevention: An International Journal: Vol. 6: Iss. 1: Article 13.

Available at: https://digitalcommons.usf.edu/gsp/vol6/iss1/13

This Document is brought to you for free and open access by the Open Access Journals at Digital Commons @ University of South Florida. It has been accepted for inclusion in Genocide Studies and Prevention: An International Journal by an authorized editor of Digital Commons @ University of South Florida. For more information, please contact digitalcommons@usf.edu. 


\title{
Research Note: American Initiatives for the Relief of Greek Refugees, 1922-1923
}

\author{
Antonis Klapsis \\ Adjunct Lecturer, Department of Political Science and \\ International Relations, University of Peloponnese
}

In September 1922, after more than three years of war in Asia Minor, the Greek army was defeated by the Nationalist Turkish powers led by Mustafa Kemal. The atrocities from the part of the Turkish armed forces against the Christian populations of Asia Minor that followed the retreat of the Greek Army resulted in the death of hundreds of thousands of people as well as the destruction of many Christian properties. Moreover, hundreds of thousands of Greeks from Asia Minor, Pontus, and Eastern Thrace were forced to flee to Greece in order to protect themselves from Kemal's advancing Nationalist army. This article focuses on the various initiatives undertaken by the United States government and American charitable organizations, mainly the American Red Cross and Near East Relief, in order to relieve the victims of the Asia Minor Disaster. In this context, it is underlined that the United States showed the most tangible interest in that direction and that the American assistance during the first year after the Disaster helped save the lives of literally thousands of refugees.

Key words: Greek refugees, Asia Minor Disaster, American Red Cross, Near East Relief, the United States

\section{Introduction}

In September 1922, after more than three years of war in Asia Minor, the Greek army was defeated by the Nationalist Turkish powers led by Mustafa Kemal. The atrocities from the part of the Turkish armed forces against the Christian populations of Asia Minor that followed the retreat of the Greek Army resulted in the death of hundreds of thousands of people ${ }^{1}$ as well as the destruction of much Christian property. Moreover, hundreds of thousands of Greeks from Asia Minor, Pontus, and Eastern Thrace were forced to leave their birthplaces and fled to Greece to find a safe shelter in order to protect themselves from the advancing Nationalist army of Mustafa Kemal. ${ }^{2}$

This article focuses on the various initiatives undertaken by the United States government and American charitable organizations, mainly the American Red Cross and Near East Relief, in order to relieve the victims of the Asia Minor Disaster. In this context, it will be underlined that the United States showed the most tangible interest in that direction and that the American assistance during the first year after the Disaster helped save the lives of literally thousands of refugees. This of course is not a detailed account of the splendid help given by American institutions to Greek refugees from September 1922 until the summer of the following year; it can be seen however as a first frame that gives an overall impression of the subject which is yet to be further and more deeply investigated.

Antonis Klapsis, "American Initiatives for the Relief of Greek Refugees, 1922-1923," Genocide Studies and Prevention 6, 1 (April 2011): 98-106. (C) 2011 Genocide Studies and Prevention. doi:10.3138/gsp.6.1.98 


\section{The Refugee Problem and Early American Initiatives to Confront It}

The massive exodus of the Greek population created a huge refugee problem with which Greece was unable to deal all by itself. More than a million people poured into Greece, ${ }^{3}$ most of whom had no practical means of sustenance while at the same time they faced several fatal epidemics. The problem became even worse as a result of the fact that, since much of the able-bodied male Greek population of Anatolia between the productive ages of 18 and 45 were killed or taken prisoners, the refugees from Asia Minor and Pontus consisted principally of women, children, and old men, ${ }^{4}$ which meant that many refugee families lacked their natural protectors and were in even greater difficulty to make a living on their own. The urgent need to relieve the refugees, which indeed exceeded the capability of the Greek government, meant that the contribution of the international community was absolutely essential. Thus, in October 1922, the former Prime Minister and a leading political figure of Greece, Eleftherios Venizelos, made a public appeal, asking for the active assistance of the whole world; however, given the fact Europe was recovering from World War I, Venizelos pointed out that any substantial assistance would have to come from the United States. ${ }^{5}$

Venizelos's appeal to the United States was based on the fact that the American authorities had already-from the first days of September 1922-shown tangible interest in the tragic fate of the Greek refugees from Anatolia. As early as September 6 the Unites States High Commissioner at Constantinople, Admiral Mark Lambert Bristol, in close collaboration with representatives of American relief and benevolent institutions in Constantinople, had organized a disaster relief committee for Smyrna, ${ }^{6}$ the biggest city on the west coast of Asia Minor where thousands of refugees from the Anatolian interior had already poured. At the same time, the American Red Cross and the Near East Relief, the most prominent American charitable institutions operating in the region, had, as a first practical measure, made available $\$ 25,000$ for the assistance of refugees. ${ }^{7}$

As the situation worsened from day to day, on September 8 the Greek government made an urgent appeal to the American Chargé d'Affaires at Athens, Jefferson Caffery, asking for the immediate assistance of the US government to help save the hundreds of thousands of refugees that were assembled in Asia Minor ports. Greece appeared willing to receive these refugees, but as Greek vessels were employed in evacuating the retreating Greek troops from Asia Minor, there were no available means to bring the refugees to Greece. As a result, Athens asked Washington to provide ships for the safe transportation of the refugees as well as food and tents for their relief when they would arrive in Greece. ${ }^{8}$ The fact that on September 9 the Turkish Army took control of Smyrna meant that the issue had to be solved without any further delay. ${ }^{9}$

The problem of food shortage had been immediately understood by the members of the representatives of US humanitarian organizations, such as the American Red Cross and the Near East Relief, which were engaged with the relief of refugees at Smyrna. In fact, the institutions of this kind were in practice the only institutions working on the spot for the relief of refugees. ${ }^{10}$ In this context, Admiral Bristol was pointing out "the extreme gravity of the condition of refugees at Smyrna and elsewhere," about 300,000 of whom were entirely destitute-there was practically no hope that they would be able to return to their homes as their personal safety could not be secured; moreover, the situation was predicted to become even worse owing to the approach of winter. ${ }^{11}$ 
The gravity of the problem made the representatives of the American Red Cross and the Near East Relief hesitant as to whether private charity alone would be adequate for the relief of the hundreds of thousands of Greek refugees. According to these two organizations, all money available would be used up within two or three weeks and the situation would still be as pressing at the end of that time "unless this breathing spell were used to put into action some comprehensive scheme to reduce and ultimately solve the problem." Thus, the American Red Cross and the Near East Relief pointed out that government action by the Western Allies was absolutely essential. ${ }^{12}$ Admiral Bristol was also entirely in accord with the view that private charity alone was quite unequal to the situation. Moreover, he suggested that American relief activities should be restricted to Anatolia in giving aid to refugees who were awaiting evacuation, and that "the task of evacuating these refugees and providing for them at their ultimate destinations should be urged upon Greek and Allied Governments". ${ }^{13}$

However, as the rest of the Allied governments (namely those of Great Britain, France, and Italy) were reluctant to take any practical measure for the assistance of the refugees, the US government decided to act by itself. By September 20 neither the Italian nor the British High Commissioners at Constantinople had received any instructions from their respective governments and as a result no action for the assistance of the refugees had been taken. ${ }^{14}$ According to press reports, the only relief work being carried out in Smyrna was conducted by the American Red Cross, the Near East Relief, and United States Navy Destroyers in the region and the only foreign forces ashore were American sailors. ${ }^{15}$ Furthermore, Admiral Bristol instructed the dispatch of yet another destroyer at Smyrna to assist with the evacuation of the refugees whose lives were in great danger:

Without waiting for the allies to act and in view of the unexpected evacuation of refugees to the interior from Smyrna, we will take all possible steps to meet the present emergency and the latter facts induced me to give orders to use the limited number of destroyers I have available to assist in the evacuation. ${ }^{16}$

The situation for the refugees continued to deteriorate rapidly. Those who were still trying to find a means to leave Asia Minor and find shelter in Greece were facing the immediate danger of dying either because of the massacres by the Kemalist forces or because of hunger and diseases. Things were not much better for the refugees who had managed to escape the slaughter as they were almost equally exposed to the danger of hunger and diseases. Caffery from Athens reported that the Greek government was in fact unable to undertake the extremely difficult task of housing and feeding the refugees. As money and food were badly needed, Caffery recommended that American relief organizations should urgently send assistance to Greece. ${ }^{17}$

Caffery's appeal was in accordance with the initiatives of his government. In a telegram sent on September 21 to Admiral Bristol, the Under Secretary of State, William Phillips, described in detail the steps which had been taken by the United States to prepare for extended relief work. Among these were the following: President Warren G. Harding had asked Congress to appropriate $\$ 200,000$ for the relief and possible repatriation of destitute American citizens living in Asia Minor; in addition to the $\$ 25,000$ already advanced, the American Red Cross had informally indicated willingness to make a further advance for a possible total of $\$ 100,000$; the Near East Relief had addressed a general appeal throughout the United States for an emergency fund and in addition to funds resulting from this appeal it was estimated that it would be able to make advances for a possible total of $\$ 200,000$; 
finally, the Young Men's Christian Association (YMCA) had advanced $\$ 10,000$ and there was a possibility of further advances. ${ }^{18}$

For his part, Admiral Bristol suggested that the only practical means that the Greek government could use to undertake the enormous task of refugee relief was by immediately demobilizing the Greek army. This would mean that the Greek government could handle all the relief work in Greece and that American relief organizations would not be drawn into operations in Greece that would involve large expenditures of money and more or less permanent activities. In the meantime, Admiral Bristol, in close coordination with members of various American charitable organizations, had taken certain measures to facilitate the safe evacuation and relief of refugees in Smyrna, Moudania, Bursa, and Rodosto. ${ }^{19}$

The gravity and the urgency of the situation were so overwhelming that the need for immediate action was essential. Thus, despite the fact that the US government agreed with Admiral Bristol that the responsibility for the evacuation and the relief of Greek refugees rested primarily with Greece and the Allied governments, the Greek Red Cross had already made a direct appeal for help to the American Red Cross and the Near East Relief was contemplating a possible extension of its work to Greece. ${ }^{20}$ At the same time, the Disaster Relief Committee in Smyrna, which in fact represented all of the American relief organizations in the wider region, was issuing no less than 20,000 rations of food per day in Smyrna, US destroyers were helping with the evacuation of Greeks from the city, and flour was sent to various places (such as Smyrna, Rodosto, and Mytilene) where many refugees were located. Moreover, contributions from different associations collected by the Disaster Relief Committee amounted to $\$ 85,000 . .^{21}$

\section{Private Charity in Action}

By the end of September 1922, through the instrumentality of various American relief associations, funds and supplies summing approximately $\$ 300,000$ had been made available for the relief of Greek refugees. Meanwhile, American emergency relief units continued to work on the ground, mainly in places where huge numbers of refugees had poured in on their way to Greece, such as Smyrna, Moudania, Bursa, and Rodosto, and US war vessels continued to help in the difficult task of the evacuation of refugees. ${ }^{22}$ Nevertheless, no matter how great American help was, there were still many things to be done so that the lives of hundreds of thousands of refugees could be saved. Thus, in his statement issued on 9 October 1922 regarding relief work in the Near East, President Harding announced that due to an emergency appeal the American Red Cross and the Near East Relief would jointly continue their relief efforts and that a special fund under the name Near East Emergency Fund would be created and collect donations from every part of the United States. ${ }^{23}$ The American Red Cross was to be in charge of the operations in Greece while the Near East Relief would concentrate its activities in Turkey where thousands of Greeks, among whom there were many orphans, were still trying to find a safe way to Greece.

In fact, the American Red Cross was immediately prepared to send a mission to Athens to assist in the administration of relief measures to the numerous Greek refugees, provided that (1) this mission would be approved by the Greek authorities and (2) these authorities would be prepared to offer full protection for personnel and provide storage and transportation facilities for the necessary supplies. ${ }^{24}$ This was an offer that Athens could not refuse. Thus, the Greek government was delighted to express its deep gratitude to the American Red Cross for its generous offer and 
promised to provide all the desired facilities ${ }^{25}$ to help with the relief work. In fact, the situation in Greece was so critical and the means available to the Greek authorities for the relief of refugees were so insufficient that, when the first representatives of the American Red Cross arrived in Athens, the Greek government was actually considering handing over to the American Red Cross the entire charge of the Ministry of Public Assistance. ${ }^{26}$ Of course, the American Red Cross was in no position to undertake such a responsibility; however, the help provided by this as well as other American charitable organizations was so significant that in January 1923 the newly crowned King of the Greeks George II expressed his personal thanks to President Harding for America's generous assistance. ${ }^{27}$

Indeed, the Relief Commission of the American Red Cross established in Greece since October 1922 did marvelous work as far as the relief of Greek refugees was concerned. The degree of its contribution is evident in the fact that in March 1923 more than 533,000 refugees received food supplies daily and about 291,000 had been inoculated against diseases such as typhus and cholera by agents of the American Red Cross, ${ }^{28}$ not to mention the clothes and other necessary supplies that were distributed among refugees. However, it was evident that the American charitable organizations, mainly the American Red Cross, could not carry out the extremely difficult task of relieving the hundreds of thousands of Greek refugees who had found shelter on Greek soil for much longer. As a result, in late January 1923 the American Red Cross Commissioner for Greece, Colonel William N. Haskell, suggested that the American Red Cross should cease its operations in June of the same year and make an early announcement of its intention so that plenty of time would be given "to the Greek government and all others concerned to make their arrangements properly." 29

In accordance with Colonel Haskell's suggestions, the American Red Cross decided to terminate its emergency work in Greece by 30 June 1923. This decision was taken not only because it was difficult to find further resources, but also on the ground that the solution of the refugee problem in Greece could not lie in measures of temporary relief alone but rather in measures of a permanent character that would enable the refugees to be absorbed as promptly as possible into the normal economic life of Greece. In other words, it would be advisable for the refugees not to depend for much longer on charity but rather to become self-sufficient. For the same reasons, the Near East Relief had also decided to terminate its emergency relief for adult refugees and concentrate its efforts mainly on orphans and children in need..$^{30}$

The Greek government wished to persuade the American Red Cross to continue its relief operations after 30 June 1923. In fact, in late May 1923 the Greek government made a formal request of the kind to the American Red Cross, stating that Greece would not be able to undertake the care of refugees until six months after the signature of the peace treaty with Turkey which, at the time of the submission of the request, had not yet been concluded. ${ }^{31}$ The American Red Cross, however, was not willing to change its decision and the Vice President of the Central Committee in Charge of International Relations of the American Red Cross, Ernest P. Bichnell, explained why:

I feel that it is important to make it necessary that Greece shall be made to feel her full responsibility in the circumstances. Our withdrawal should have a tendency to compel the breaking up of the concentration camps and a wider distribution of the refugees throughout the country. Without the breaking up no progress can be made toward the absorption of the refugees into the normal population or their establishment on self support. Possibly, too, the pressure of the full burden of responsibility for the refugees will have a wholesome effect on governmental policies. ${ }^{32}$ 
In this context, the US government had already asked the governments of Great Britain, France, and Italy to provide substantial help to Greece so that the latter could cope with the relief of refugees. ${ }^{33}$ This American initiative was additional proof that the American officials were justly convinced that the solution of the refugee problem did not lie in measures of temporary relief, but in measures of a more permanent character.

As it had in good time been announced, the American Red Cross officially terminated its relief work in Greece on 30 June 1923. Four days earlier the Municipality of Athens had organized an official ceremony in which King George II, the Greek Prime Minister, members of the Cabinet, and other officials thanked the members of the American Red Cross for their invaluable help. ${ }^{34}$ Moreover, by mid-August of the same year the Near East Relief ended its relief work for adults ${ }^{35}$ and continued its actions only for orphans and children in need. However, before closing its operations, the American Red Cross had distributed rations of food to the refugees that would be sufficient for one month or, in some cases, even for two months, while a small amount of clothing and child-feeding supplies were left to be distributed by the local Greek authorities. As a result, even as it withdrew from Greece, the American Red Cross provided relief for at least one month longer. ${ }^{36}$ Moreover, with the American stocks left over and given the excellent crop prospects, American officials estimated that the Greek authorities could meet the needs of refugees until November $1923 .^{37}$

\section{Conclusion}

It is not easy to sufficiently underline the importance of the American charitable initiatives from September 1922 until the summer of the following year. Indeed, the lives of hundreds of thousands of Greek refugees from Asia Minor, Pontus, and Eastern Thrace were saved thanks to the humanitarian initiatives of American charitable organizations, mainly the American Red Cross and the Near East Relief. These two organizations practically single-handedly undertook the extremely difficult task of providing aid on the spot to Greek refugees who otherwise would have likely been condemned to death by diseases, malnutrition, and other hardships. The gravity of the situation demanded immediate and effective action and the United States was by far the first to respond to the Greek appeals for help.

Sometimes the numbers speak for themselves even though they cannot always describe the splendor of philanthropy. The total cost of the relief work undertaken by the American Red Cross for the period from October 1922 to 30 June 1923 amounted to the astonishing $\$ 2,605,696.09 .{ }^{38}$ During that period of time, the American Red Cross took care of the feeding and nursing of more than 500,000 Greek refugees, and the Near East Relief helped in the relief of several thousand Greeks, including many orphans, who had not yet left Asia Minor and were trying to find a safe way of going to Greece. After the withdrawal of the American Red Cross from Greece, it was estimated that the Greek government would need about 12 to 15 million drachmas (that is approximately $\$ 375,000$ to $\$ 470,000$ ) per month in order to only feed the refugees who were in no position to sustain themselves. ${ }^{39}$ It is quite obvious that, without this assistance, the Greek government would not have been able to cope with the extremely heavy burden of providing the means of survival to hundreds of thousands of Greek refugees and it is easy to imagine what the fate of many of them would have been if in the critical first months after the Asia Minor Disaster the United States had not offered its generous help to Greece. 


\section{Notes}

1. Justin McCarthy, Muslims and Minorities: The Population of Ottoman Anatolia and the End of the Empire (New York: New York University Press, 1983), 132-33.

2. Besides the Greeks, there were also more than 50,000 Armenians who sought refuge in Greece. See League of Nations Official Journal, no. 1 (1923), 133.

3. According to the official Greek census of 1928, 1,104,216 people from Asia Minor, Pontus, Eastern Thrace, and Istanbul had moved to Greece, of whom only 86,422 (7.8\%) before

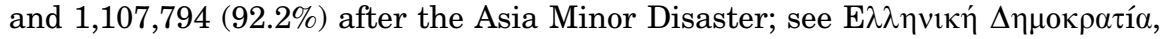

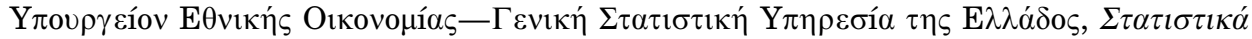

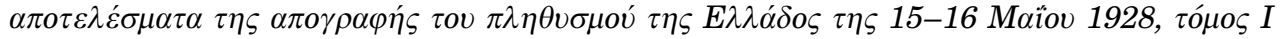

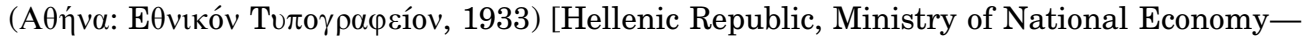
General Statistical Survey of Greece, Statistical Results of the Population Census of Greece of 15-16 May 1928, volume I (Athens: National Printing Office, 1933)], 26, from where the figures of the following table are extracted:

\begin{tabular}{lccr}
\hline & $\begin{array}{l}\text { Before the Asia Minor } \\
\text { Disaster }\end{array}$ & $\begin{array}{l}\text { After the Asia Minor } \\
\text { Disaster }\end{array}$ & Total \\
\hline Asia Minor & 37,728 & 589,226 & 626,954 \\
Pontus & 17,528 & 164,641 & 182,169 \\
Eastern Thrace & 27,057 & 229,578 & 256,635 \\
Istanbul & 4,109 & 34,349 & 38,458 \\
\hline Total & 86,422 & $1,017,794$ & $1,104,216$ \\
\hline
\end{tabular}

4. League of Nations, Official Journal, no. 1 (1923), 135. See also "The Representative of the Greek Government (Vouros) to the Chief of the Division of Near Eastern Affairs, Department of State (Dulles)," Washington, 10 October 1922, United States of America Department of State, Papers Relating to the Foreign Relations of the United States, 1922, vol. II (Washington: United States Government Printing Office, 1938) [FRUS, 1922, vol. II], 940-41. According to the Greek census of 1928, the percentage of widow refugee women aged 20-59 was more than 50\% higher than that of the average female population. See Hellenic Republic, Ministry of National Economy-General Statistical Survey of Greece, Statistical Results, 50.

5. Dimitri Pentzopoulos, The Balkan Exchange of Minorities and Its Impact on Greece (London: Hurst, 2002), 77.

6. "The High Commissioner at Constantinople (Bristol) to the Acting Secretary of State," Constantinople, 6 September 1922, FRUS, 1922, vol. II, 415-16.

7. "The Acting Secretary of State to the High Commissioner at Constantinople (Bristol)," Washington, 8 September 1922, FRUS, 1922, vol. II, 416; “The Acting Secretary of State to the Ambassador in Great Britain (Harvey)," Washington, 15 September 1923, FRUS, 1922, vol. II, 423-24.

8. "The Chargé in Greece (Caffery) to the Acting Secretary of State," Athens, 8 September 1922, FRUS, 1922, vol. II, 416-17.

9. The dates used in this article follow the Gregorian Calendar (new calendar) as opposed to the Julian Calendar (old calendar) which was in use in Greece until 15 February 1923. It has to be noted that by that time the Julian Calendar differed from the Gregorian one by thirteen days. For example, 14 September 1922 in the Gregorian Calendar was 1 September 1922 in the Julian Calendar.

10. "The High Commissioner at Constantinople (Bristol) to the Acting Secretary of State," Constantinople, 10 September 1922, FRUS, 1922, vol. II, 418-19.

11. "The High Commissioner at Constantinople (Bristol) to the Acting Secretary of State," Constantinople, 13 September 1922, FRUS, 1922, vol. II, 420-21. 
12. "The Acting Secretary of State to the Ambassador in Great Britain (Harvey)," Washington, 15 September 1922, FRUS, 1922, vol. II, 423-24.

13. "The High Commissioner at Constantinople (Bristol) to the Acting Secretary of State," Constantinople, 18 September 1922, FRUS, 1922, vol. II, 424-25.

14. "The High Commissioner at Constantinople (Bristol) to the Acting Secretary of State," Constantinople, 20 September 1922, FRUS, 1922, vol. II, 427-29.

15. "The Acting Secretary of State to the High Commissioner at Constantinople (Bristol)," Washington, 19 September 1922, FRUS, 1922, vol. II, 426.

16. "The High Commissioner at Constantinople (Bristol) to the Acting Secretary of State," Constantinople, 20 September 1922, FRUS, 1922, vol. II, 427-29.

17. "The Chargé in Greece (Caffery) to the Acting Secretary of State, Athens," 20 September 1922, FRUS, 1922, vol. II, 429.

18. "The Acting Secretary of State to the High Commissioner at Constantinople (Bristol)," Washington, 21 September 1922, FRUS, 1922, vol. II, 430-31.

19. "The High Commissioner at Constantinople (Bristol) to the Acting Secretary of State," Constantinople, 22 September 1922, FRUS, 1922, vol. II, 431-32. For more details on the evacuation of Greek refugees from Smyrna, see Christos Papoutsy, Ships of Mercy: The True Story of the Rescue of the Greeks, Smyrna, September 1922 (Portsmouth, New Hampshire: Peter E. Randall, 2008).

20. "The Acting Secretary of State to the Chargé in Greece (Caffery)," Washington, 22 September 1922, FRUS, 1922, vol. II, 432-33.

21. "The High Commissioner at Constantinople (Bristol) to the Secretary of State," Constantinople, 25 September 1922, FRUS, 1922, vol. II, 433-35.

22. "The Secretary of State to the Ambassador in Great Britain (Harvey)," Washington, 29 September 1922, FRUS, 1922, vol. II, 437.

23. "The Secretary of State to the High Commissioner at Constantinople (Bristol)," Washington, 9 October 1922, FRUS, 1922, vol. II, 438.

24. "The Secretary of State to the Chargé in Greece (Caffery)," Washington, 9 October 1922, FRUS, 1922, vol. II, 439.

25. "The Chargé in Greece (Caffery) to the Secretary of State," Athens, 11 October 1922, FRUS, 1922, vol. II, 440.

26. "The Chargé in Greece (Caffery) to the Secretary of State," Athens, 31 October 1922, FRUS, 1922, vol. II, 443.

27. "The Secretary of State to the Chargé in Greece (Caffery)," Washington, 5 January 1923, FRUS, 1922, vol. II, 449.

28. The American National Red Cross: Annual Report for the Year Ending, June 30, 1923 (Washington: 1923), 64-65.

29. "The American Red Cross Commissioner for Greece (Haskell) to the Chairman of the American Red Cross (Payne)," Athens, 29 January 1923, United States of America Department of State, Papers Relating to the Foreign Relations of the United States, 1923, vol. II (Washington: United States Government Printing Office, 1938) [FRUS, 1923, vol. II], 318-19.

30. "The Secretary of State to the British Ambassador (Geddes)," Washington, 31 March 1923, FRUS, 1923, vol. II, 329-31.

31. The Lausanne Peace Treaty was eventually signed on 24 July 1923.

32. "The Vice President, Central Committee in Charge of Foreign Operations, American Red Cross (Bicknell) to the Under Secretary of State (Phillips)," Paris, 23 May 1923, FRUS, 1923, vol. II, 338-39.

33. "The Secretary of State to the British Ambassador (Geddes)," Washington, 31 March 1923, FRUS, 1923, vol. II, 329-31.

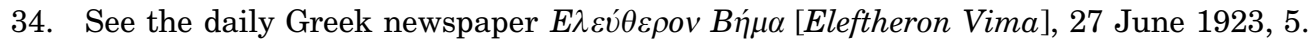

35. "The Secretary of State to the Chargé in Greece (Atherton)," Washington, 4 August 1923, FRUS, 1923, vol. II, 359 . 
36. "The High Commissioner at Constantinople (Bristol) to the Secretary of State," Constantinople, 10 July 1923, FRUS, 1923, vol. II, 352-53.

37. "The Special Mission at Lausanne to the Secretary of State," Lausanne, 26 June 1923, FRUS, 1923, vol. II], 345-46.

38. The American National Red Cross, 90.

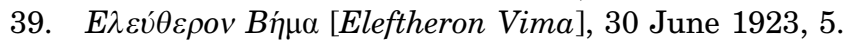

